\title{
REVIEW
}

\section{Effects of androgens on cardiovascular remodeling}

\author{
Yasumasa Ikeda ${ }^{1,2}$, Ken-ichi Aihara ${ }^{2}$, Sumiko Yoshida ${ }^{2}$, Masashi Akaike ${ }^{3}$ and Toshio Matsumoto ${ }^{2}$ \\ Departments of ${ }^{1}$ Pharmacology, ${ }^{2}$ Medicine and Bioregulatory Sciences and ${ }^{3}$ Medical Education, The University of Tokushima, Graduate School of Health \\ Biosciences, 3-18-15 Kuramoto-cho, Tokushima 770-8503, Japan \\ (Correspondence should be addressed to K Aihara; Email: aihara@clin.med.tokushima-u.ac.jp)
}

\begin{abstract}
Androgens, the male sex hormones, exert various biological effects on many target organs through the transcriptional effects of the nuclear androgen receptor (AR). ARs are expressed not only in classical target organs, such as the brain, genital organs, bone, and skeletal muscles, but also in the cardiovascular system. Because the female sex hormones estrogens are wellknown to protect against cardiovascular disease, sex has been considered to have a significant clinical impact on

cardiovascular mortality. However, the influence of androgens on the cardiovascular system has not been fully elucidated. To clarify this issue, we analyzed the effects of administration of angiotensin II and doxorubicin, an anticancer agent, in a loading model in male wild-type and AR-deficient mice. In this review, we focus on the actions of androgens as potential targets for the prevention of cardiovascular diseases in males. Journal of Endocrinology (2012) 214, 1-10
\end{abstract}

\section{Introduction}

Cardiovascular disease remains a major cause of death in both women and men worldwide and appears to increase morbidity and mortality in industrial countries. The various risk factors for development of cardiovascular disease include aging, hypertension, dyslipidemia, diabetes, obesity, and smoking. In addition to these cardiovascular risk factors, there are several sex differences in cardiovascular disease. The incidence of cardiovascular disease is approximately twofold higher in males than in females (Kalin \& Zumoff 1990). This sex discrepancy in cardiovascular disease rates has been thought to be associated with sex hormone-mediated actions. Estrogens, which are female sex hormones, are generally considered to exert favorable effects against cardiovascular diseases. Many studies have revealed preventive and favorable effects of estrogen on cardiac hypertrophy (Malhotra et al. 1990, Weinberg et al. 1999, van Eickels et al. 2001, Cavasin et al. 2003) and vascular remodeling (Zhang et al. 2000).

In contrast, male sex is generally believed to be one of the major cardiovascular risk factors, along with other traditional determinants such as hypertension, hyperlipidemia, diabetes, and smoking (Criqui 1986). Therefore, the male sex hormones, androgens, are thought to be detrimental to cardiovascular organs. In fact, androgen replacement is associated with cardiovascular-related adverse events in aged men who have limitations in mobility (Basaria et al. 2010).
In addition, previous studies have shown that testosterone replacement tends to increase cardiovascular risk among men of all ages (Calof et al. 2005, Haddad et al. 2007, Fernandez-Balsells et al. 2010). On the other hand, recent epidemiological studies have revealed that lower testosterone levels in men are associated with higher mortality rates, due largely to cardiovascular disease (Khaw et al. 2007, Laughlin et al. 2008, Tivesten et al. 2009, Yeap et al. 2009, Akishita et al. 2010, Corona et al. 2010, Malkin et al. 2010, Araujo et al. 2011; Fig. 1). Moreover, patients undergoing androgendeprivation therapy for prostate cancer are at increased risk of coronary heart disease and heart failure (Martin-Merino et al. 2011). It has been reported that low testosterone is associated with metabolic syndrome or diabetes in men (Stanworth \& Jones 2009, Grossmann 2011). Prospective studies have also revealed that men with higher testosterone level have a low risk of type 2 diabetes (Ding et al. 2006).

Although the mechanisms of the heart- and blood vesselprotective activities of androgens remain unclear, recent studies have shown preventive effects of androgens against cardiovascular disease. In addition, analysis of androgen receptor (AR)-knockout (KO) mice (Sato et al. 2003) has revealed new aspects of the functional activities of androgens in various tissues, including adipocytes (Sato et al. 2003, Fan et al. 2005), brain (Sato et al. 2004), bone (Kawano et al. 2003), and cardiovascular organs (Ikeda et al. 2005, 2009, 2010). Thus, the androgen-AR system plays an important 


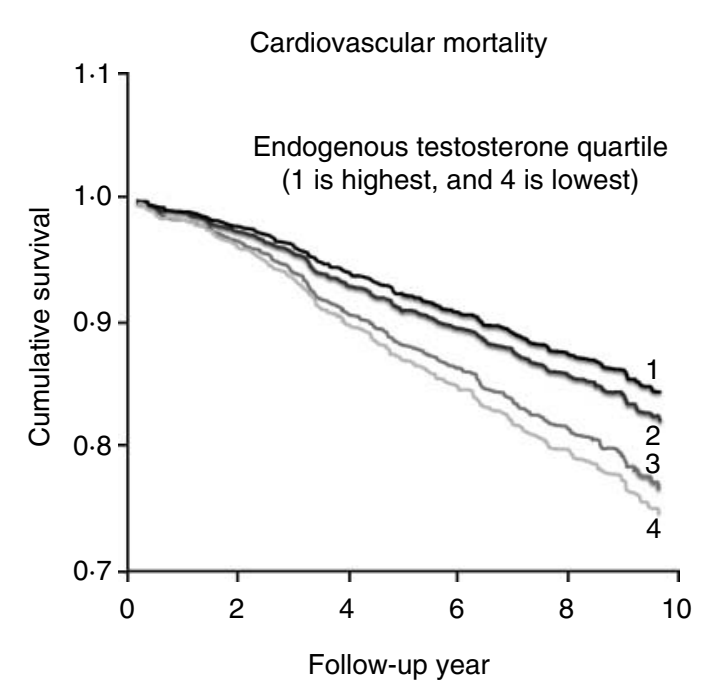

Figure 1 Relationship between serum testosterone level and cardiovascular mortality in men. Reduced levels of endogenous testosterone worsen the mortality of cardiovascular disease in men, indicating that testosterone is a predictive factor of cardiovascular disease. (Modified from Khaw et al. (2007)).

role in homeostasis of various organs in males, although the favorable effects of androgens remain controversial.

In this review, we give an overview of the pathophysiological roles of androgen activity in the cardiovascular system and focus on the cardiovascular stress-induced phenotypes observed in male ARKO mice in order to elucidate the effect of AR against cardiovascular diseases.

\section{Male sex hormones, androgens}

Androgens in the human body comprise testosterone, dihydrotestosterone (DHT), androstenedione, and dehydroepiandrosterone (DHEA) and its sulfate DHEAS. Most of the testosterone is secreted by the testis. Approximately $5 \%$ of the serum testosterone produced in men undergoes $5 \alpha$-reduction to form a more potent androgen, DHT. DHT has threefold greater affinity than testosterone and 15- to 30-fold greater affinity than adrenal androgens for ARs. DHEA and DHEAS, the most abundant adrenal steroids in humans, are precursors for intracellular production of androgens and estrogens in nonreproductive tissues. Most of the DHEA in blood exists as DHEAS, with 300-fold more DHEAS than free DHEA. Therefore, DHEAS is the most physiologically active of this class of adrenal steroids in humans. Most testosterone exists as forms bound to plasma proteins, including $40-50 \%$ bound to albumin and $50-60 \%$ strongly bound to sex hormonebinding globulin (SHBG), with 1-2\% being free (Dunn et al. 1981). Both free testosterone and albumin-bound testosterone are fractions available for biological action, so-called bioavailable testosterone. On the other hand, SHBG-bound testosterone is not a readily bioactive form (Cefalu et al. 1986). DHT also strongly binds to SHBG, and only $0.8 \%$ is a free fraction. Other androgens including DHEA and DHEAS are bound to albumin (Plager 1965).

The levels of all androgens increase at puberty and peak during adolescence, then gradually decrease with age (Giusti et al. 1975).

\section{Mechanisms of androgen activity via AR activation}

The actions of androgens are initiated by the binding of androgens to the AR. AR, a 110-kDa ligand-inducible nuclear receptor, is a member of the nuclear receptor superfamily. The effects of androgens are generally mediated by AR activation (Chang et al. 1988a,b, Orlic et al. 2001). The biological actions of androgens via transcriptional regulation of target genes by the AR are referred to as 'genomic action' (Orlic et al. 2001). Initially, androgen enters the cells and binds to AR; the ligandbound $\mathrm{AR}$ then dimerizes and translocates into the nucleus, and binds to specific androgen response element sites located within the promoter regions of the target genes to modulate their transcriptional activities. Androgens also exert effects through extranuclear-nontranscriptional action, known as nongenomic action (Losel et al. 2003, Simoncini \& Genazzani 2003). Nongenomic androgen effects are distinct from genomic action in that they are exerted for a shorter time. Nongenomic androgen activity involves rapid induction of second messenger signal transduction cascades, including upregulation of cytosolic calcium concentration and activation of protein kinase $\mathrm{A}$, protein kinase $\mathrm{C}$ (PKC), and MAP kinases (Kousteni et al. 2002). The nongenomic action of androgen might exert, in part, through stimulating protein kinase A and cAMP via binding to G-protein coupled membrane receptor for the SHBG-testosterone complex (Heinlein \& Chang 2002; Fig. 2).

\section{AR expression in cardiovascular tissues}

Androgens exert biological effects on many target organs (Mooradian et al. 1987, Wilson 1999). While AR expression is highest in male sex organs (Wilson \& French 1976), the AR is known to be widely if weakly expressed in other tissues, including skeletal muscle (Snochowski et al. 1980), bone (Riggs et al. 2002), and the brain (McGill et al. 1980). The AR is also found in cardiac myocytes (McGill et al. 1980, Marsh et al. 1998), endothelial cells, vascular smooth muscle cells, and fibroblasts (Horwitz \& Horwitz 1982, Lin et al. 1982). Therefore, androgen-AR effects are also thought to be exerted on the heart and vasculature.

\section{Androgen effects on cardiac remodeling}

The $A R$ gene is expressed in mammalian cardiomyocytes (McGill et al. 1980, Marsh et al. 1998), indicating that androgens might have a function in the heart. The estrogen 


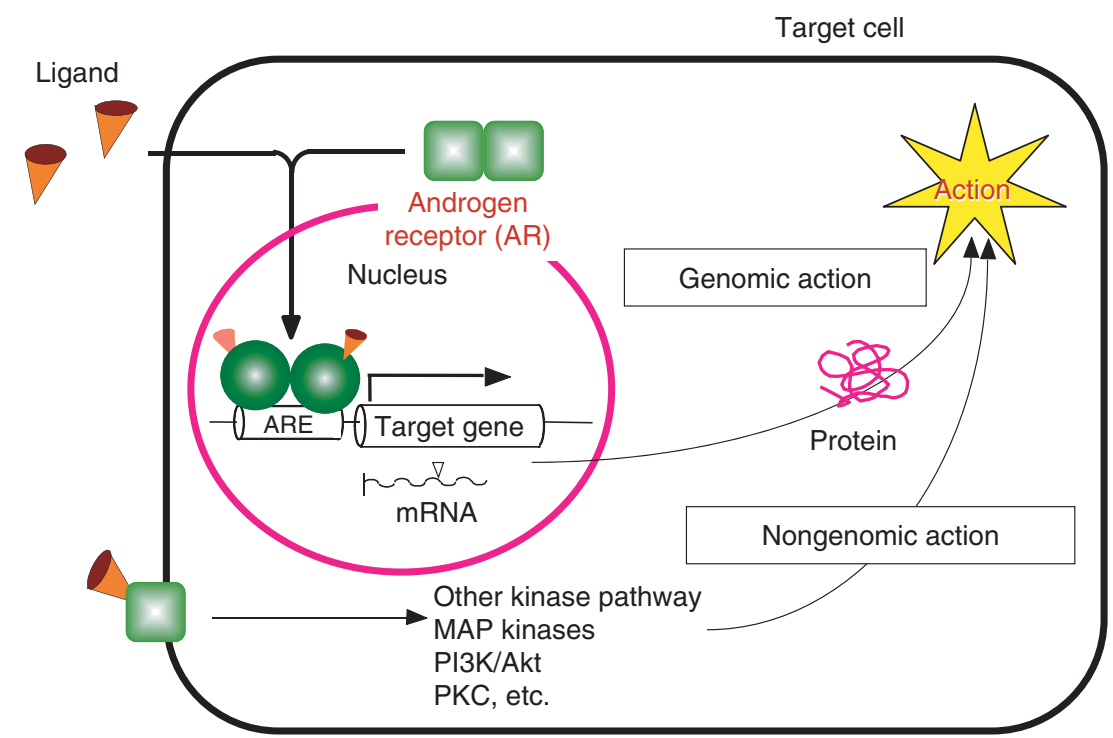

Figure 2 Biological actions of androgens via ARs. Androgen binds to the AR. The liganded AR forms homodimers and moves it into the nucleus to bind to specific DNA elements referred to androgen-responsive elements in target gene promoters and regulates the target gene expression at the transcriptional level. This action of the AR is called genomic action. Androgen-AR also exerts its function without transcription by interaction with other signaling pathways. This action is called nongenomic action.

receptor gene also exists in cardiomyocytes (Grohe et al. 1997, 1998), and many studies have shown preventive effects of estrogen on cardiac hypertrophy (Malhotra et al. 1990, Weinberg et al. 1999, Cavasin et al. 2003). However, the physiological actions of androgens in the heart have remained unclear compared with those of estrogen. Marsh et al. (1998) have shown that androgen exerts a hypertrophic effect on cardiac myocytes via a direct AR-mediated pathway, and other studies have also shown that androgens induce cardiac hypertrophy (Malhotra et al. 1990, Weinberg et al. 1999, Cavasin et al. 2003), while castration (Morano et al. 1990, Cavasin et al. 2003, Li et al. 2004) and flutamide (Baltatu et al. 2002), an AR antagonist, remarkably reduce cardiac hypertrophy. In addition, androgens modulate male cardiac performance by regulating the functional expression of L-type calcium channels in cardiac myocytes (Golden et al. 2003). Li et al. (2004) showed that castration mitigated not only cardiac hypertrophy but also cardiac fibrosis in male guanylyl cyclase-A-deficient mice.

In the clinical setting, male patients with chronic heart failure exhibit declines in serum androgen levels (Anker et al. 1997, Kiilavuori et al. 1999, Moriyama et al. 2000, Kontoleon et al. 2003), and deficiencies in circulating androgens, including testosterone, in men with chronic heart failure have been shown to be independent predictors of poor outcome (Jankowska et al. 2010). On the other hand, administration of testosterone with moderate heart failure has been shown to reduce left ventricular mass index, indicating the amelioration of cardiac hypertrophy without improving cardiac function. The effects of physiological androgen levels on cardiac remodeling and function thus remain controversial, and the molecular mechanisms of the underlying effects of androgens on the heart are still a matter of debate.

\section{Approach for study of androgen activity: overview and aberrant cardiac remodeling in ARKO mice}

The effects of androgens on the cardiovascular system are usually studied in animal models using castration or pharmacological interventions. While gonadectomy is indeed an easy way to eliminate androgen activity in vivo, the $\mathrm{AR}$ itself is still present in the castrated animal model. Flutamide, an AR antagonist, has been used for treatment of prostate cancer and also to clarify the influence of androgen activity blockade in numerous experimental studies. However, flutamide activates estrogen receptors, complicating the understanding of AR action. To elucidate the physiological function of the androgen-AR system in nonclassical target organs in vivo, we used the Cre-loxP system to generate ARKO mice (Sato et al. 2003). Male ARKO mice exhibit extremely low serum levels of testosterone and DHT, while estrogen levels are similar between male ARKO and wildtype (WT) mice. Therefore, ARKO mice are a unique animal model with a normal estrogen-ER system. Studies using ARKO mice have in recent years provided several new insights into the androgen-AR system. Male ARKO mice 
demonstrate late-onset obesity (Sato et al. 2003), with decreased energy expenditure and enhanced insulin sensitivity (Fan et al. 2005), disordered hypothalamic leptin signaling (Fan et al. 2008), high turnover osteopenia (Kawano et al. 2003), impaired brain masculinization (Sato et al. 2004), dysregulation of the pituitary glucocorticoid feedback system (Miyamoto et al. 2007), enhanced hair growth (Naito et al. 2008), and altered skeletal muscle strength (Chambon et al. 2010). ARKO mice are thus a useful tool for investigating androgen-AR activity in classical and nonclassical target organs and may have advantages over conventional models such as gonadectomized animals or administration of AR antagonists. Therefore, we used male ARKO mice to clarify the physiological role of the androgen-AR system in the heart. AR regulates physiological cardiac growth and modulates cardiac adaptive hypertrophy and fibrosis during angiotensin II (Ang II)-induced cardiac remodeling (Fig. 3; Ikeda et al. 2005). Ang II-treated ARKO mice showed the reduced activation of extracellular signal-regulated kinases (ERKs) $1 / 2$ and 5, hypertrophy-related signaling pathways, acceleration of the transforming growth factor- $\beta 1$ (TGF- $\beta 1$ )-Smad pathway, and increased expression of genes related to fibrotic change in the heart. The AR also counteracts doxorubicin (Dox)-induced cardiotoxicity, in part via activation of the Akt pathway, which upregulates TFAM and reduces oxidative stress and thus protects cardiac myocytes against mitochondrial damage and apoptosis (Fig. 4; Ikeda et al. 2010). These findings might account for the effect of testosterone replacement in male patients with severe heart failure (Malkin et al. 2006).

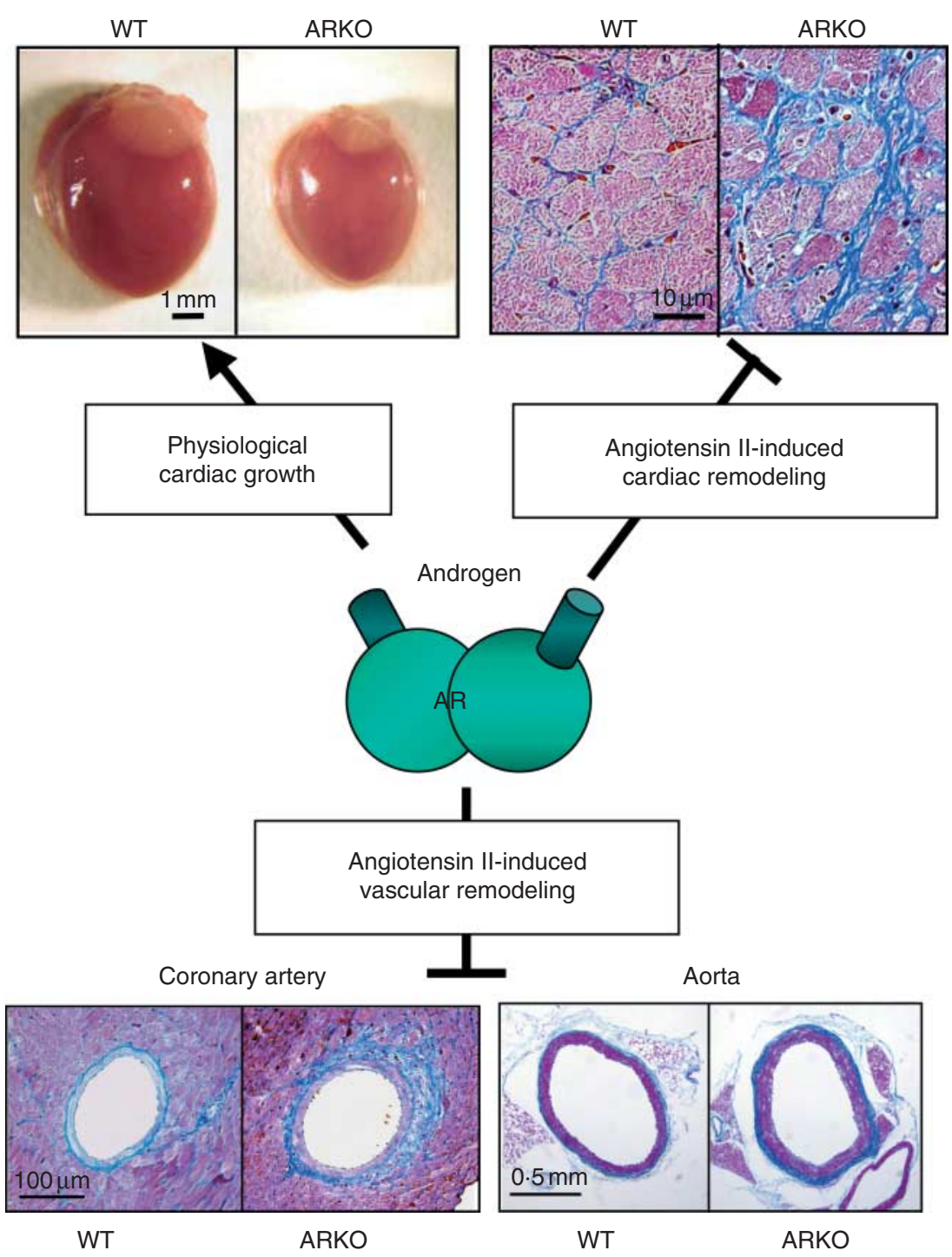

Figure 3 The AR system participates in physiological cardiac growth and inhibits angiotensin II-induced cardiovascular remodeling. (Modified from Ikeda et al. $(2005,2009)$ ). 


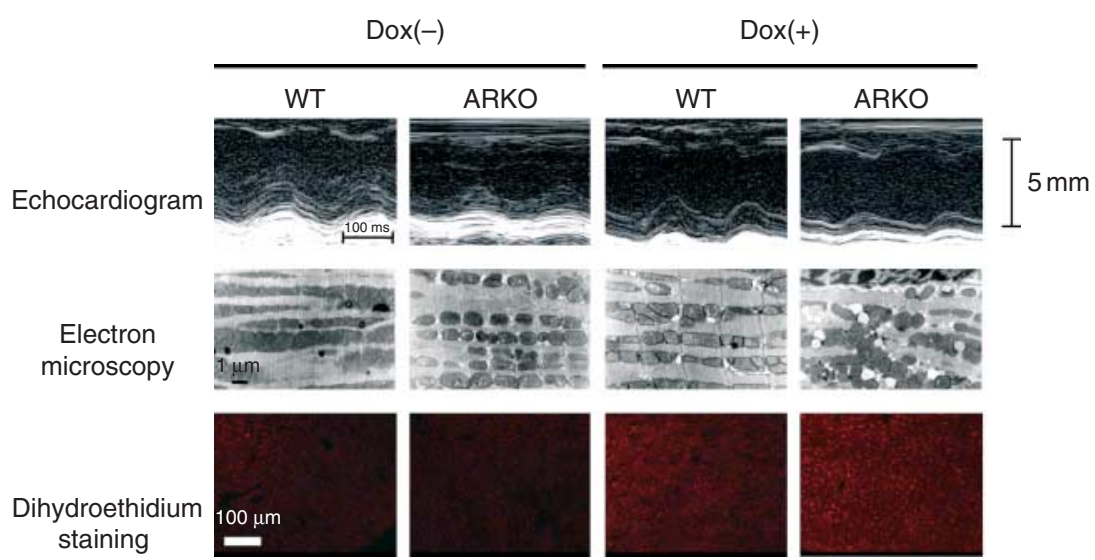

Figure 4 ARKO mice are susceptible to Dox-induced cardiotoxicity. (Upper panels) Echocardiography shows greater reduction of cardiac systolic function in Dox-treated ARKO mice than in Dox-treated WT mice. (Middle panels) Electron microscopy shows larger numbers of cardiac vacuoles and abnormal mitochondrial formation in Dox-treated ARKO mice. (Lower panels) Dox-induced cardiac superoxide production is accelerated in Dox-treated ARKO mice relative to Dox-treated WT mice. (Modified from Ikeda et al. (2010)).

\section{Effects of androgens on vascular remodeling}

The effects of androgens on blood vessels are also controversial. As male sex is one of the major risk factors for the development of cardiovascular disease, it is hypothesized that androgens promote atherosclerosis. In fact, several in vivo and in vitro studies have suggested that androgens increase expression of proatherogenic factors (Adams et al. 1995, McCrohon et al. 1999, Ng et al. 2003, Nheu et al. 2011). In contrast, recent clinical studies have shown that low endogenous testosterone levels are associated with advanced atherosclerosis of the carotid artery in middleaged males and that this association is independent of the traditional cardiovascular risk factors (Muller et al. 2004, Makinen et al. 2005). Low testosterone level is also associated with poor vasodilation of the brachial artery and is an independent risk factor for endothelial dysfunction in men (Akishita et al. 2007). Androgen replacement has been shown to prevent aortic atherosclerotic changes in castrated male rabbits fed a high cholesterol diet (Alexandersen et al. 1999), and arterial AR mRNA upregulation by testosterone has been shown to reduce neointimal plaque formation in male rabbits (Hanke et al. 2001). Endogenous testosterone also inhibits coronary neointimal formation after balloon injury through enhanced expression of PKC $\delta$ and p27 (kip1; Tharp et al. 2009). Qiu et al. (2010) showed that physiological levels of DHT attenuated the development of atherosclerosis by AR-mediated suppression of the formation of intimal foam cells by macrophages. Furthermore, we have reported that DHEAS level is inversely associated with carotid atherosclerosis, as measured by increased max-intima-media thickness (IMT) and mean-IMT, in males but not in females (Yoshida et al. 2010). Therefore, in order to elucidate the pathophysiological roles of AR activity in the cardiovascular system, we studied male ARKO mice under vascular stress (Ikeda et al. 2009). Male ARKO mice exhibited exaggerated Ang II-induced medial thickening and perivascular fibrosis in the coronary artery and aorta. Ang II-induced oxidative stress was exacerbated and nitric oxide bioavailability decreased in male ARKO mice. Androgen activity thus influences Ang II-induced vascular remodeling by suppressing oxidative stress and preserving nitric oxide production (Ikeda et al. 2009). Androgen-AR system-promoted eNOS activation was mediated by both phosphatidylinositol 3-kinase (PI3K)/Akt signaling and the direct interaction of AR with p85 $\alpha$ (Ikeda et al. 2010, Koizumi et al. 2010). In addition, AR deletion in Apo-E-deficient mice accelerated the atherosclerotic changes; this effect was partially attenuated by androgen supplementation (Bourghardt $e t$ al. 2010). Interestingly, physiological testosterone supplementation inhibited cholesterol-enriched diet-induced fatty streak formation in $\mathrm{Tfm}$ mice, which have a deletion in the gene encoding the classical $A R$ (Nettleship et al. 2007). These results suggested that androgen exerts an atheroprotective effect via AR-dependent and -independent signaling. The androgen-AR system thus protects vascular remodeling through multiple signaling pathways.

\section{The effects of androgens on angiogenesis}

While the effect of estrogens on angiogenesis has been studied extensively and characterized in detail (Losordo \& Isner 2001), very little is known about the effect of androgens on angiogenesis. As proof that the androgen-AR system is involved in angiogenesis, Sieveking et al. (2010a) demonstrated both in vitro and in vivo that androgens elicit an AR-mediated angiogenic effect in males but not in females. 


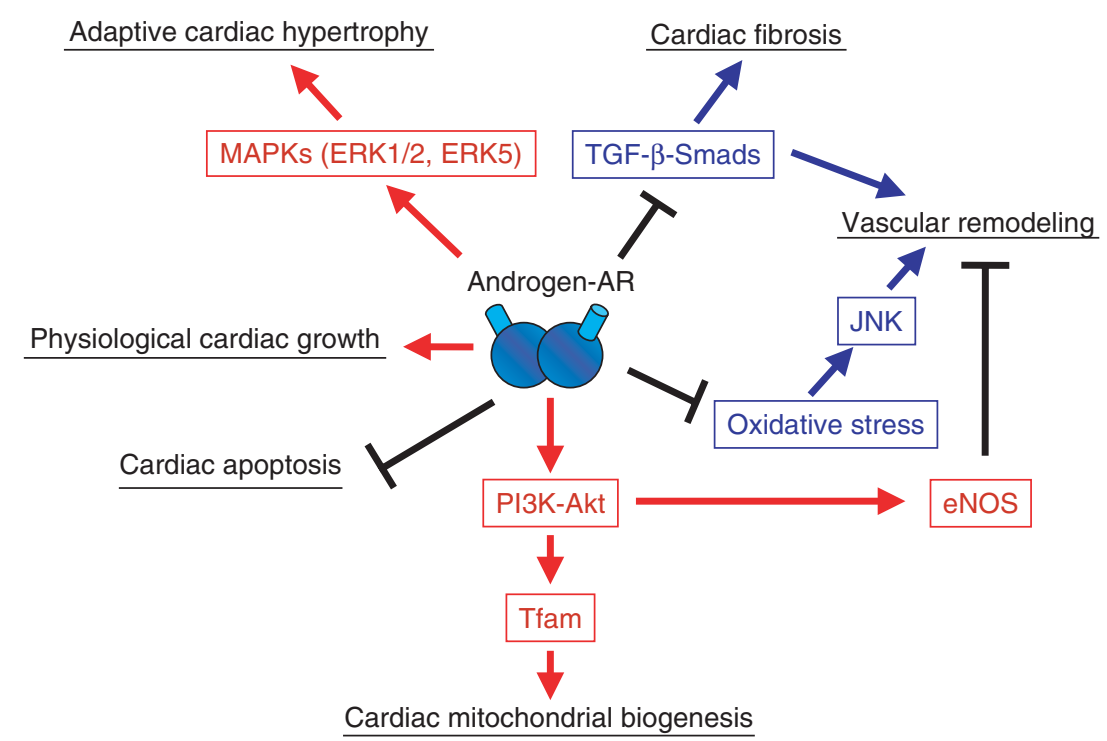

Figure 5 Schematic diagram of cardiovascular-protective effects of ligand-bound AR.

They concluded that androgens promote angiogenesis via vascular endothelial growth factor (VEGF)-related mechanisms (Cai et al. 2011) and also by stimulation of erythropoietin production (Sieveking et al. 2010a,b). Further studies are necessary to clarify the significance of androgens in angiogenesis.

\section{Androgens and peripheral arterial disease}

Peripheral arterial disease (PAD) not only decreases quality of life due to intermittent claudication, but also, more importantly, is a powerful predictor of future cardiovascular and cerebrovascular events such as myocardial infarction, stroke, and death (Smith et al. 1990, Criqui et al. 1992, Murabito et al. 2003). Previous clinical studies have shown that PAD is two- to three-fold more prevalent in men than in women (Dormandy \& Rutherford 2000) and that low testosterone levels are associated with lower extremity PAD in elderly men (Tivesten et al. 2007). Conversely, it has been reported that sex hormones are not associated with the development of PAD in men or postmenopausal women (Price et al. 1997). Therefore, the pathophysiological roles of androgen activity in the development of PAD remain a matter of debate.

\section{Androgens and hypertension}

It has been believed that blood pressure is higher in males than in females after puberty (Burt et al. 1995) and that there are sex differences in the prevalence and complications of hypertension. Indeed, patients undergoing androgendeprivation therapy due to prostate cancer showed decreased central arterial compliance (Dockery et al. 2000), and several studies have shown that low serum testosterone level is associated with high blood pressure in elderly men (Fogari et al. 2005, Akishita et al. 2010) and that suppression of testosterone production increases arterial stiffness (Dockery et al. 2003). In addition, testosterone replacement therapy has been shown to improve arterial stiffness in elderly hypogonadal men (Yaron et al. 2009). These findings suggest that physiological androgen levels preserve appropriate blood pressure by modulating vascular stiffness.

In experimental animal models, castration reduced blood pressure in male rats with spontaneous (Martin et al. 2005, Ojeda et al. 2007) or fructose feeding-induced (Song et al. 2004) hypertension. Testosterone has also been shown to inhibit L-type calcium channels via an AR-independent pathway, indicating nongenomic action of androgen on vasodilatation (Scragg et al. 2004, 2007, Hall et al. 2006). However, we have found that there is no difference in blood pressure between male ARKO and age-matched WT mice at 6 months of age (Ikeda et al. 2005). As the results of these animal studies are inconsistent with the results of clinical human studies, further research on the mechanisms by which androgens affect blood pressure is required.

\section{Conclusion}

Although androgens, in contrast to estrogen, have been considered to have adverse effects on the cardiovascular system, recent studies have revealed favorable effects of androgens on cardiovascular remodeling. Based on these previous results, at least physiological levels of androgens are thought to be required for cardiovascular homeostasis in males. As a better understanding of the sex differences in 
cardiovascular diseases might lead to novel therapeutic strategies, the pathophysiology of the involvement of sex hormones in the cardiovascular system must be determined in detail. Figure 5 shows a conceptual summary of the currently known pathophysiological activities of ligand-bound AR described in this review.

\section{Declaration of interest}

The authors declare that there is no conflict of interest that could be perceived as prejudicing the impartiality of the research reported.

\section{Funding}

This work was supported in part by Grants-in-Aid for Scientific Research and Young Scientist B from the Ministry of Education, Culture, Sports, Science, and Technology of Japan and a Grant for a Study Group on Aseptic Femoral Neck Necrosis from the Ministry of Health, Labour and Welfare of Japan.

\section{References}

Adams MR, Williams JK \& Kaplan JR 1995 Effects of androgens on coronary artery atherosclerosis and atherosclerosis-related impairment of vascular responsiveness. Arteriosclerosis, Thrombosis, and Vascular Biology 15 562-570. (doi:10.1161/01.ATV.15.5.562)

Akishita M, Hashimoto M, Ohike Y, Ogawa S, Iijima K, Eto M \& Ouchi Y 2007 Low testosterone level is an independent determinant of endothelial dysfunction in men. Hypertension Research 30 1029-1034. (doi:10.1291/ hypres.30.1029)

Akishita M, Hashimoto M, Ohike Y, Ogawa S, Iijima K, Eto M \& Ouchi Y 2010 Low testosterone level as a predictor of cardiovascular events in Japanese men with coronary risk factors. Atherosclerosis 210 232-236. (doi:10.1016/j.atherosclerosis.2009.10.037)

Alexandersen P, Haarbo J, Byrjalsen I, Lawaetz H \& Christiansen C 1999 Natural androgens inhibit male atherosclerosis: a study in castrated, cholesterol-fed rabbits. Circulation Research 84 813-819. (doi:10.1161/01. RES.84.7.813)

Anker SD, Chua TP, Ponikowski P, Harrington D, Swan JW, Kox WJ, Poole-Wilson PA \& Coats AJ 1997 Hormonal changes and catabolic/ anabolic imbalance in chronic heart failure and their importance for cardiac cachexia. Circulation 96 526-534. (doi:10.1161/01.CIR.96.2.526)

Araujo AB, Dixon JM, Suarez EA, Murad MH, Guey LT \& Wittert GA 2011 Clinical review: endogenous testosterone and mortality in men: a systematic review and meta-analysis. Journal of Clinical Endocrinology and Metabolism 96 3007-3019. (doi:10.1210/jc.2011-1137)

Baltatu O, Cayla C, Iliescu R, Andreev D, Jordan C \& Bader M 2002 Abolition of hypertension-induced end-organ damage by androgen receptor blockade in transgenic rats harboring the mouse ren-2 gene. Journal of the American Society of Nephrology 13 2681-2687. (doi:10.1097/01. ASN.0000033327.65390.CA)

Basaria S, Coviello AD, Travison TG, Storer TW, Farwell WR, Jette AM, Eder R, Tennstedt S, Ulloor J, Zhang A et al. 2010 Adverse events associated with testosterone administration. New England Journal of Medicine 363 109-122. (doi:10.1056/NEJMoa1000485)

Bourghardt J, Wilhelmson AS, Alexanderson C, De Gendt K, Verhoeven G, Krettek A, Ohlsson C \& Tivesten A 2010 Androgen receptor-dependent and independent atheroprotection by testosterone in male mice. Endocrinology 151 5428-5437. (doi:10.1210/en.2010-0663)

Burt VL, Cutler JA, Higgins M, Horan MJ, Labarthe D, Whelton P, Brown C \& Roccella EJ 1995 Trends in the prevalence, awareness, treatment, and control of hypertension in the adult US population. Data from the health examination surveys, 1960 to 1991. Hypertension 26 60-69. (doi:10.1161/ 01.HYP.26.1.60)

Cai J, Hong Y, Weng C, Tan C, Imperato-McGinley J \& Zhu YS 2011 Androgen stimulates endothelial cell proliferation via an androgen receptor/VEGF/cyclin A-mediated mechanism. American Journal of Physiology. Heart and Circulatory Physiology 300 H1210-H1221. (doi:10.1152/ajpheart.01210.2010)

Calof OM, Singh AB, Lee ML, Kenny AM, Urban RJ, Tenover JL \& Bhasin S 2005 Adverse events associated with testosterone replacement in middleaged and older men: a meta-analysis of randomized, placebo-controlled trials. Journals of Gerontology. Series A, Biological Sciences and Medical Sciences 60 1451-1457. (doi:10.1093/gerona/60.11.1451)

Cavasin MA, Sankey SS, Yu AL, Menon S \& Yang XP 2003 Estrogen and testosterone have opposing effects on chronic cardiac remodeling and function in mice with myocardial infarction. American Journal of Physiology. Heart and Circulatory Physiology 284 H1560-H1569. (doi:10.1152/ajpheart. 01087.2002)

Cefalu WT, Pardridge WM, Chaudhuri G \& Judd HL 1986 Serum bioavailability and tissue metabolism of testosterone and estradiol in rat salivary gland. Journal of Clinical Endocrinology and Metabolism 63 20-28. (doi:10.1210/jcem-63-1-20)

Chambon C, Duteil D, Vignaud A, Ferry A, Messaddeq N, Malivindi R, Kato S, Chambon P \& Metzger D 2010 Myocytic androgen receptor controls the strength but not the mass of limb muscles. PNAS 107 14327-14332. (doi:10.1073/pnas.1009536107)

Chang CS, Kokontis J \& Liao ST 1988 a Molecular cloning of human and rat complementary DNA encoding androgen receptors. Science 240 324-326. (doi:10.1126/science.3353726)

Chang CS, Kokontis J \& Liao ST $1988 b$ Structural analysis of complementary DNA and amino acid sequences of human and rat androgen receptors. PNAS 85 7211-7215. (doi:10.1073/pnas.85.19.7211)

Corona G, Monami M, Boddi V, Cameron-Smith M, Fisher AD, de Vita G, Melani C, Balzi D, Sforza A, Forti G et al. 2010 Low testosterone is associated with an increased risk of MACE lethality in subjects with erectile dysfunction. Journal of Sexual Medicine 7 1557-1564. (doi:10.1111/j.17436109.2009.01690.x)

Criqui MH 1986 Epidemiology of atherosclerosis: an updated overview. American Journal of Cardiology 57 18C-23C. (doi:10.1016/0002-9149 (86)91022-2)

Criqui MH, Langer RD, Fronek A, Feigelson HS, Klauber MR, McCann TJ \& Browner D 1992 Mortality over a period of 10 years in patients with peripheral arterial disease. New England Journal of Medicine 326 381-386. (doi:10.1056/NEJM199202063260605)

Ding EL, Song Y, Malik VS \& Liu S 2006 Sex differences of endogenous sex hormones and risk of type 2 diabetes: a systematic review and meta-analysis. Journal of the American Medical Association 295 1288-1299. (doi:10.1001/ jama.295.11.1288)

Dockery F, Rajkumar C, Agarwal S, Waxman J \& Bulpitt CJ 2000 Androgen deprivation in males is associated with decreased central arterial compliance and reduced central systolic blood pressure. Journal of Human Hypertension 14 395-397. (doi:10.1038/sj.jhh.1001028)

Dockery F, Bulpitt CJ, Agarwal S, Donaldson M \& Rajkumar C 2003 Testosterone suppression in men with prostate cancer leads to an increase in arterial stiffness and hyperinsulinaemia. Clinical Science 104 195-201. (doi:10.1042/CS20020209)

Dormandy JA \& Rutherford RB 2000 Management of peripheral arterial disease (PAD). TASC Working Group. TransAtlantic Inter-Society Consensus (TASC). Journal of Vascular Surgery 31 S1-S296. (doi:10.1016/ S0741-5214(00)81002-2)

Dunn JF, Nisula BC \& Rodbard D 1981 Transport of steroid hormones: binding of 21 endogenous steroids to both testosterone-binding globulin and corticosteroid-binding globulin in human plasma. Journal of Clinical Endocrinology and Metabolism 53 58-68. (doi:10.1210/jcem-53-1-58) van Eickels M, Grohe C, Cleutjens JP, Janssen BJ, Wellens HJ \& Doevendans PA 2001 17 $\beta$-Estradiol attenuates the development of pressure-overload hypertrophy. Circulation 104 1419-1423. (doi:10.1161/hc3601.095577) 
Fan W, Yanase T, Nomura M, Okabe T, Goto K, Sato T, Kawano H, Kato S \& Nawata H 2005 Androgen receptor null male mice develop late-onset obesity caused by decreased energy expenditure and lipolytic activity but show normal insulin sensitivity with high adiponectin secretion. Diabetes $\mathbf{5 4}$ 1000-1008. (doi:10.2337/diabetes.54.4.1000)

Fan W, Yanase T, Nishi Y, Chiba S, Okabe T, Nomura M, Yoshimatsu H, Kato S, Takayanagi R \& Nawata H 2008 Functional potentiation of leptinsignal transducer and activator of transcription 3 signaling by the androgen receptor. Endocrinology 149 6028-6036. (doi:10.1210/en.2008-0431)

Fernandez-Balsells MM, Murad MH, Lane M, Lampropulos JF, Albuquerque F, Mullan RJ, Agrwal N, Elamin MB, Gallegos-Orozco JF, Wang AT et al. 2010 Clinical review 1: adverse effects of testosterone therapy in adult men: a systematic review and meta-analysis. Journal of Clinical Endocrinology and Metabolism 95 2560-2575. (doi:10.1210/jc.2009-2575)

Fogari R, Preti P, Zoppi A, Fogari E, Rinaldi A, Corradi L \& Mugellini A 2005 Serum testosterone levels and arterial blood pressure in the elderly. Hypertension Research 28 625-630. (doi:10.1291/hypres.28.625)

Giusti G, Gonnelli P, Borrelli D, Fiorelli G, Forti G, Pazzagli M \& Serio M 1975 Age-related secretion of androstenedione, testosterone and dihydrotestosterone by the human testis. Experimental Gerontology 10 241-245. (doi:10.1016/0531-5565(75)90001-7)

Golden KL, Marsh JD, Jiang Y, Brown T \& Moulden J 2003 Gonadectomy of adult male rats reduces contractility of isolated cardiac myocytes. American Journal of Physiology. Endocrinology and Metabolism 285 E449-E453. (doi:10.1152/ajpendo.00054.2003)

Grohe C, Kahlert S, Lobbert K, Stimpel M, Karas RH, Vetter H \& Neyses L 1997 Cardiac myocytes and fibroblasts contain functional estrogen receptors. FEBS Letters 416 107-112. (doi:10.1016/S0014-5793(97) 01179-4)

Grohe C, Kahlert S, Lobbert K \& Vetter H 1998 Expression of oestrogen receptor alpha and beta in rat heart: role of local oestrogen synthesis. Journal of Endocrinology 156 R1-R7. (doi:10.1677/joe.0.156R001)

Grossmann M 2011 Low testosterone in men with type 2 diabetes: significance and treatment. Journal of Clinical Endocrinology and Metabolism 96 2341-2353. (doi:10.1210/jc.2011-0118)

Haddad RM, Kennedy CC, Caples SM, Tracz MJ, Bolona ER, Sideras K, Uraga MV, Erwin PJ \& Montori VM 2007 Testosterone and cardiovascular risk in men: a systematic review and meta-analysis of randomized placebocontrolled trials. Mayo Clinic Proceedings 82 29-39. (doi:org/10.4065/82.1.29)

Hall J, Jones RD, Jones TH, Channer KS \& Peers C 2006 Selective inhibition of L-type $\mathrm{Ca}^{2+}$ channels in A7r5 cells by physiological levels of testosterone. Endocrinology 147 2675-2680. (doi:10.1210/en.2005-1243)

Hanke H, Lenz C, Hess B, Spindler KD \& Weidemann W 2001 Effect of testosterone on plaque development and androgen receptor expression in the arterial vessel wall. Circulation 103 1382-1385. (doi:10.1161/01.CIR. 103.10.1382)

Heinlein CA \& Chang C 2002 The roles of androgen receptors and androgenbinding proteins in nongenomic androgen actions. Molecular Endocrinology 16 2181-2187. (doi:10.1210/me.2002-0070)

Horwitz KB \& Horwitz LD 1982 Canine vascular tissues are targets for androgens, estrogens, progestins, and glucocorticoids. Journal of Clinical Investigation 69 750-758. (doi:10.1172/JCI110513)

Ikeda Y, Aihara K, Sato T, Akaike M, Yoshizumi M, Suzaki Y, Izawa Y, Fujimura M, Hashizume S, Kato M et al. 2005 Androgen receptor gene knockout male mice exhibit impaired cardiac growth and exacerbation of angiotensin II-induced cardiac fibrosis. Journal of Biological Chemistry 280 29661-29666. (doi:10.1074/jbc.M411694200)

Ikeda Y, Aihara K, Yoshida S, Sato T, Yagi S, Iwase T, Sumitomo Y, Ise T, Ishikawa K, Azuma H et al. 2009 Androgen-androgen receptor system protects against angiotensin II-induced vascular remodeling. Endocrinology 150 2857-2864. (doi:10.1210/en.2008-1254)

Ikeda Y, Aihara K, Akaike M, Sato T, Ishikawa K, Ise T, Yagi S, Iwase T, Ueda Y, Yoshida S et al. 2010 Androgen receptor counteracts doxorubicininduced cardiotoxicity in male mice. Molecular Endocrinology 24 1338-1348. (doi:10.1210/me.2009-0402)

Jankowska EA, Drohomirecka A, Ponikowska B, Witkowska A, Lopuszanska M, Szklarska A, Borodulin-Nadzieja L, Banasiak W, Poole-Wilson PA \& Ponikowski P 2010 Deficiencies in circulating testosterone and dehydroepiandrosterone sulphate, and depression in men with systolic chronic heart failure. European Journal of Heart Failure 12 966-973. (doi:10. 1093/eurjhf/hfq108)

Kalin MF \& Zumoff B 1990 Sex hormones and coronary disease: a review of the clinical studies. Steroids 55 330-352. (doi:10.1016/0039-128X (90)90058-J)

Kawano H, Sato T, Yamada T, Matsumoto T, Sekine K, Watanabe T, Nakamura T, Fukuda T, Yoshimura K, Yoshizawa T et al. 2003 Suppressive function of androgen receptor in bone resorption. PNAS 100 9416-9421. (doi:10.1073/pnas.1533500100)

Khaw KT, Dowsett M, Folkerd E, Bingham S, Wareham N, Luben R, Welch A \& Day N 2007 Endogenous testosterone and mortality due to all causes, cardiovascular disease, and cancer in men: European prospective investigation into cancer in Norfolk (EPIC-Norfolk) Prospective Population Study. Circulation 116 2694-2701. (doi:10.1161/CIRCULATIONAHA.107.719005)

Kiilavuori K, Naveri H, Leinonen H \& Harkonen M 1999 The effect of physical training on hormonal status and exertional hormonal response in patients with chronic congestive heart failure. European Heart Journal 20 456-464. (doi:10.1053/euhj.1998.1277)

Koizumi H, Yu J, Hashimoto R, Ouchi Y \& Okabe T 2010 Involvement of androgen receptor in nitric oxide production induced by icariin in human umbilical vein endothelial cells. FEBS Letters $\mathbf{5 8 4}$ 2440-2444. (doi:10. 1016/j.febslet.2010.04.049)

Kontoleon PE, Anastasiou-Nana MI, Papapetrou PD, Alexopoulos G, Ktenas V, Rapti AC, Tsagalou EP \& Nanas JN 2003 Hormonal profile in patients with congestive heart failure. International Journal of Cardiology 87 179-183. (doi:10.1016/S0167-5273(02)00212-7)

Kousteni S, Chen JR, Bellido T, Han L, Ali AA, O'Brien CA, Plotkin L, Fu Q, Mancino AT, Wen Y et al. 2002 Reversal of bone loss in mice by nongenotropic signaling of sex steroids. Science 298 843-846. (doi:10.1126/science.1074935)

Laughlin GA, Barrett-Connor E \& Bergstrom J 2008 Low serum testosterone and mortality in older men. Journal of Clinical Endocrinology and Metabolism 93 68-75. (doi:10.1210/jc.2007-1792)

Li Y, Kishimoto I, Saito Y, Harada M, Kuwahara K, Izumi T, Hamanaka I, Takahashi N, Kawakami R, Tanimoto K et al. 2004 Androgen contributes to gender-related cardiac hypertrophy and fibrosis in mice lacking the gene encoding guanylyl cyclase-A. Endocrinology 145 951-958. (doi:10.1210/en. 2003-0816)

Lin AL, McGill HC Jr \& Shain SA 1981 Hormone receptors of the baboon cardiovascular system. Biochemical characterization of aortic and myocardial cytoplasmic androgen receptors. Circulation Research 49 1010-1016. (doi:10.1161/01.RES.49.4.1010)

Losel RM, Falkenstein E, Feuring M, Schultz A, Tillmann HC, Rossol-Haseroth K \& Wehling M 2003 Nongenomic steroid action: controversies, questions, and answers. Physiological Reviews 83 965-1016. (doi:10.1152/physrev.00003.2003)

Losordo DW \& Isner JM 2001 Estrogen and angiogenesis: a review. Arteriosclerosis, Thrombosis, and Vascular Biology 21 6-12. (doi:10.1161/01. ATV.21.1.6)

Makinen J, Jarvisalo MJ, Pollanen P, Perheentupa A, Irjala K, Koskenvuo M, Makinen J, Huhtaniemi I \& Raitakari OT 2005 Increased carotid atherosclerosis in andropausal middle-aged men. Journal of the American College of Cardiology 45 1603-1608. (doi:10.1016/j.jacc.2005.01.052)

Malhotra A, Buttrick P \& Scheuer J 1990 Effects of sex hormones on development of physiological and pathological cardiac hypertrophy in male and female rats. American Journal of Physiology 259 H866-H871.

Malkin CJ, Pugh PJ, West JN, van Beek EJ, Jones TH \& Channer KS 2006 Testosterone therapy in men with moderate severity heart failure: a doubleblind randomized placebo controlled trial. European Heart Journal 27 57-64. (doi:10.1093/eurheartj/ehi443)

Malkin CJ, Pugh PJ, Morris PD, Asif S, Jones TH \& Channer KS 2010 Low serum testosterone and increased mortality in men with coronary heart disease. Heart 96 1821-1825. (doi:10.1136/hrt.2010.195412)

Marsh JD, Lehmann MH, Ritchie RH, Gwathmey JK, Green GE \& Schiebinger RJ 1998 Androgen receptors mediate hypertrophy in cardiac myocytes. Circulation 98 256-261. (doi:10.1161/01.CIR.98.3.256) 
Martin DS, Biltoft S, Redetzke R \& Vogel E 2005 Castration reduces blood pressure and autonomic venous tone in male spontaneously hypertensive rats. Journal of Hypertension 23 2229-2236. (doi:10.1097/01.hjh. 0000191903.19230.79)

Martin-Merino E, Johansson S, Morris T \& Garcia Rodriguez LA 2011 Androgen deprivation therapy and the risk of coronary heart disease and heart failure in patients with prostate cancer: a Nested Case-Control Study in UK Primary Care. Drug Safety 34 1061-1077. (doi:10.2165/11594540000000000-00000)

McCrohon JA, Jessup W, Handelsman DJ \& Celermajer DS 1999 Androgen exposure increases human monocyte adhesion to vascular endothelium and endothelial cell expression of vascular cell adhesion molecule-1. Circulation 99 2317-2322. (doi:10.1161/01.CIR.99.17.2317)

McGill HC Jr, Anselmo VC, Buchanan JM \& Sheridan PJ 1980 The heart is a target organ for androgen. Science 207 775-777. (doi:10.1126/science. 6766222)

Miyamoto J, Matsumoto T, Shiina H, Inoue K, Takada I, Ito S, Itoh J, Minematsu T, Sato T, Yanase T et al. 2007 The pituitary function of androgen receptor constitutes a glucocorticoid production circuit. Molecular and Cellular Biology 27 4807-4814. (doi:10.1128/MCB.02039-06)

Mooradian AD, Morley JE \& Korenman SG 1987 Biological actions of androgens. Endocrine Reviews 8 1-28. (doi:10.1210/edrv-8-1-1)

Morano I, Gerstner J, Ruegg JC, Ganten U, Ganten D \& Vosberg HP 1990 Regulation of myosin heavy chain expression in the hearts of hypertensive rats by testosterone. Circulation Research 66 1585-1590. (doi:10.1161/01. RES.66.6.1585)

Moriyama Y, Yasue H, Yoshimura M, Mizuno Y, Nishiyama K, Tsunoda R, Kawano H, Kugiyama K, Ogawa H, Saito Y et al. 2000 The plasma levels of dehydroepiandrosterone sulfate are decreased in patients with chronic heart failure in proportion to the severity. Journal of Clinical Endocrinology and Metabolism 85 1834-1840. (doi:10.1210/jc.85.5.1834)

Muller M, van den Beld AW, Bots ML, Grobbee DE, Lamberts SW \& van der Schouw YT 2004 Endogenous sex hormones and progression of carotid atherosclerosis in elderly men. Circulation 109 2074-2079. (doi:10.1161/01.CIR.0000125854.51637.06)

Murabito JM, Evans JC, Larson MG, Nieto K, Levy D \& Wilson PW 2003 The ankle-brachial index in the elderly and risk of stroke, coronary disease, and death: the Framingham Study. Archives of Internal Medicine 163 1939-1942. (doi:10.1001/archinte.163.16.1939)

Naito A, Sato T, Matsumoto T, Takeyama K, Yoshino T, Kato S \& Ohdera M 2008 Dihydrotestosterone inhibits murine hair growth via the androgen receptor. British Journal of Dermatology 159 300-305. (doi:10.1111/j.13652133.2008.08671.x)

Nettleship JE, Jones TH, Channer KS \& Jones RD 2007 Physiological testosterone replacement therapy attenuates fatty streak formation and improves high-density lipoprotein cholesterol in the Tfm mouse: an effect that is independent of the classic androgen receptor. Circulation 116 2427-2434. (doi:10.1161/CIR CULATIONAHA.107.708768)

Ng MK, Quinn CM, McCrohon JA, Nakhla S, Jessup W, Handelsman DJ, Celermajer DS \& Death AK 2003 Androgens up-regulate atherosclerosisrelated genes in macrophages from males but not females: molecular insights into gender differences in atherosclerosis. Journal of the American College of Cardiology 42 1306-1313. (doi:10.1016/j.jacc.2003.07.002)

Nheu L, Nazareth L, Xu GY, Xiao FY, Luo RZ, Komesaroff P \& Ling S 2011 Physiological effects of androgens on human vascular endothelial and smooth muscle cells in culture. Steroids 76 1590-1596. (doi:10.1016/ j.steroids.2011.09.015)

Ojeda NB, Grigore D, Yanes LL, Iliescu R, Robertson EB, Zhang H \& Alexander BT 2007 Testosterone contributes to marked elevations in mean arterial pressure in adult male intrauterine growth restricted offspring. American Journal of Physiology. Regulatory, Integrative and Comparative Physiology 292 R758-R763. (doi:10.1152/ajpregu.00311.2006)

Orlic D, Kajstura J, Chimenti S, Limana F, Jakoniuk I, Quaini F, Nadal-Ginard B, Bodine DM, Leri A \& Anversa P 2001 Mobilized bone marrow cells repair the infarcted heart, improving function and survival. PNAS 98 10344-10349. (doi:10.1073/pnas.181177898)
Plager JE 1965 The binding of androsterone sulfate, ethiocholanolone sulfate, and dehydroisoandrosterone sulfate by human plasma protein. Journal of Clinical Investigation 44 1234-1239. (doi:10.1172/ JCI105229)

Price JF, Lee AJ \& Fowkes FG 1997 Steroid sex hormones and peripheral arterial disease in the Edinburgh Artery Study. Steroids 62 789-794. (doi:10.1016/S0039-128X(97)00103-7)

Qiu Y, Yanase T, Hu H, Tanaka T, Nishi Y, Liu M, Sueishi K, Sawamura T \& Nawata H 2010 Dihydrotestosterone suppresses foam cell formation and attenuates atherosclerosis development. Endocrinology 151 3307-3316. (doi:10.1210/en.2009-1268)

Riggs BL, Khosla S \& Melton LJ III 2002 Sex steroids and the construction and conservation of the adult skeleton. Endocrine Reviews 23 279-302. (doi:10.1210/er.23.3.279)

Sato T, Matsumoto T, Yamada T, Watanabe T, Kawano H \& Kato S 2003 Late onset of obesity in male androgen receptor-deficient (AR KO) mice. Biochemical and Biophysical Research Communications 300 167-171. (doi:10.1016/S0006-291X(02)02774-2)

Sato T, Matsumoto T, Kawano H, Watanabe T, Uematsu Y, Sekine K, Fukuda T, Aihara K, Krust A, Yamada T et al. 2004 Brain masculinization requires androgen receptor function. PNAS 101 1673-1678. (doi:10.1073/ pnas.0305303101)

Scragg JL, Jones RD, Channer KS, Jones TH \& Peers C 2004 Testosterone is a potent inhibitor of L-type $\mathrm{Ca}(2+)$ channels. Biochemical and Biophysical Research Communications 318 503-506. (doi:10.1016/j.bbrc. 2004.04.054)

Scragg JL, Dallas ML \& Peers C 2007 Molecular requirements for L-type $\mathrm{Ca}^{2+}$ channel blockade by testosterone. Cell Calcium 42 11-15. (doi:10.1016/j.ceca.2006.11.003)

Sieveking DP, Chow RW \& Ng MK 2010a Androgens, angiogenesis and cardiovascular regeneration. Current Opinion in Endocrinology, Diabetes, and Obesity 17 277-283. (doi:10.1097/MED.0b013e3283394e20)

Sieveking DP, Lim P, Chow RW, Dunn LL, Bao S, McGrath KC, Heather AK, Handelsman DJ, Celermajer DS \& Ng MK 2010b A sex-specific role for androgens in angiogenesis. Journal of Experimental Medicine 207 345-352. (doi:10.1084/jem.20091924)

Simoncini T \& Genazzani AR 2003 Non-genomic actions of sex steroid hormones. European Journal of Endocrinology 148 281-292. (doi:10.1530/eje. $0.1480281)$

Smith GD, Shipley MJ \& Rose G 1990 Intermittent claudication, heart disease risk factors, and mortality. The Whitehall Study. Circulation 82 1925-1931. (doi:10.1161/01.CIR.82.6.1925)

Snochowski M, Dahlberg E \& Gustafsson JA 1980 Characterization and quantification of the androgen and glucocorticoid receptors in cytosol from rat skeletal muscle. European Journal of Biochemistry 111 603-616. (doi:10.1111/j.1432-1033.1980.tb04977.x)

Song D, Arikawa E, Galipeau D, Battell M \& McNeill JH 2004 Androgens are necessary for the development of fructose-induced hypertension. Hypertension 43 667-672. (doi:10.1161/01.HYP.0000118018.77344.4e)

Stanworth RD \& Jones TH 2009 Testosterone in obesity, metabolic syndrome and type 2 diabetes. Frontiers of Hormone Research 37 74-90. (doi:10.1159/000176046)

Tharp DL, Masseau I, Ivey J, Ganjam VK \& Bowles DK 2009 Endogenous testosterone attenuates neointima formation after moderate coronary balloon injury in male swine. Cardiovascular Research 82 152-160. (doi:10.1093/cvr/cvp038)

Tivesten A, Mellstrom D, Jutberger H, Fagerberg B, Lernfelt B, Orwoll E, Karlsson MK, Ljunggren O \& Ohlsson C 2007 Low serum testosterone and high serum estradiol associate with lower extremity peripheral arterial disease in elderly men. The MrOS Study in Sweden. Journal of the American College of Cardiology 50 1070-1076. (doi:10.1016/j.jacc. 2007. 04.088)

Tivesten A, Vandenput L, Labrie F, Karlsson MK, Ljunggren O, Mellstrom D \& Ohlsson C 2009 Low serum testosterone and estradiol predict mortality in elderly men. Journal of Clinical Endocrinology and Metabolism 94 2482-2488. (doi:10.1210/jc.2008-2650) 
Weinberg EO, Thienelt CD, Katz SE, Bartunek J, Tajima M, Rohrbach S, Douglas PS \& Lorell BH 1999 Gender differences in molecular remodeling in pressure overload hypertrophy. Journal of the American College of Cardiology 34 264-273. (doi:10.1016/S0735-1097(99)00165-5)

Wilson JD 1999 The role of androgens in male gender role behavior. Endocrine Reviews 20 726-737. (doi:10.1210/er.20.5.726)

Wilson EM \& French FS 1976 Binding properties of androgen receptors. Evidence for identical receptors in rat testis, epididymis, and prostate. Journal of Biological Chemistry 251 5620-5629.

Yaron M, Greenman Y, Rosenfeld JB, Izkhakov E, Limor R, Osher E, Shenkerman G, Tordjman K \& Stern N 2009 Effect of testosterone replacement therapy on arterial stiffness in older hypogonadal men. European Journal of Endocrinology 160 839-846. (doi:10.1530/EJE-09-0052)

Yeap BB, Hyde Z, Almeida OP, Norman PE, Chubb SA, Jamrozik K, Flicker L \& Hankey GJ 2009 Lower testosterone levels predict incident stroke and transient ischemic attack in older men. Journal of Clinical Endocrinology and Metabolism 94 2353-2359. (doi:10.1210/jc.2008-2416)
Yoshida S, Aihara K, Azuma H, Uemoto R, Sumitomo-Ueda Y, Yagi S, Ikeda Y, Iwase T, Nishio S, Kawano H et al. 2010 Dehydroepiandrosterone sulfate is inversely associated with sex-dependent diverse carotid atherosclerosis regardless of endothelial function. Atherosclerosis 212 310-315. (doi:10.1016/ j.atherosclerosis.2010.05.011)

Zhang Y, Stewart KG \& Davidge ST 2000 Estrogen replacement reduces age-associated remodeling in rat mesenteric arteries. Hypertension $\mathbf{3 6}$ 970-974. (doi:10.1161/01.HYP.36.6.970)

Received in final form 27 March 2012

Accepted 5 April 2012

Made available online as an Accepted Preprint 5 April 2012 